(2) Open Access Full Text Article

\title{
Eggshell membrane hydrolyzates activate NF- $\kappa B$ in vitro: possible implications for in vivo efficacy
}

\author{
This article was published in the following Dove Press journal: \\ Journal of Inflammation Research \\ 9 February 2015 \\ Number of times this article has been viewed
}

\section{Kevin J Ruff ${ }^{\prime}$ \\ Paul L Durham² \\ Austin O'Reilly² \\ F Daniel Long'}

'ESM Technologies, LLC, Carthage, MO, USA; ${ }^{2}$ Center for Biomedical and Life Sciences, Missouri State University, Springfield, MO, USA

Correspondence: Kevin J Ruff ESM Technologies, LLC, 2213 Missouri Avenue, Carthage, MO 64836, USA $\mathrm{Tel}+\mathrm{I} 4173106059$

Fax + I 4173584944

Email kruff@esmingredients.com
Purpose: Eggshell membrane (ESM) has been shown to contain naturally occurring bioactive components, and biological activities such as reducing proinflammatory cytokines, liver fibrosis, and joint pain in osteoarthritis sufferers have also been reported for ESM matrix as a whole. Nuclear factor kappa-light-chain-enhancer of activated B-cells $(\mathrm{NF}-\kappa \mathrm{B})$ is a signaling protein found in the cytoplasm of nearly all human and animal cell types and is a primary regulator of immune function. The studies reported herein were designed to investigate the possible role that NF- $\kappa B$ activity might play in the reported biological activities of ESM.

Methods: Three ESM hydrolyzates produced via fermentation, enzymatic, or chemical hydrolysis were evaluated in vitro in either human peripheral blood mononuclear cell or THP-1 (human leukemic monocyte) cell cultures for NF- $\kappa \mathrm{B}$ activity following 4-hour exposure. The hydrolyzates were compared with untreated control cells or cells incubated with lipopolysaccharide or ascorbic acid. The source of ESM activity was also evaluated.

Results: NF- $\mathrm{KB}$ levels were increased above levels found in untreated cells at all three dilutions $(1: 100,1: 1,000$, and $1: 10,000)$ for the fermentation hydrolyzate of ESM (ESM-FH) $(P=0.021$, $P=0.020, P=0.009$, respectively) in peripheral blood mononuclear cells. The enzymatic hydrolyzate of ESM (ESM-EH) also produced statistically significant levels of activated NF- $\kappa$ B at the $1: 100$ and $1: 1,000$ dilutions ( $P=0.004, P=0.006$, respectively) but fell just shy of significance at the 1:10,000 dilution $(P=0.073)$. Similarly, ESM-FH $(P=0.021, P=0.002)$ and ESM-EH $(P=0.007$, $P=0.007)$ activated NF- $\mathrm{KB}$ in THP-1 cells at 1:1,000 and 1:10,000 dilutions, respectively. The chemical hydrolyzate of ESM (ESM-CH) showed statistically significant levels of activation at the $1: 1,000$ dilution $(P=0.005)$ but failed to differ from untreated cells at the 1:10,000 dilution $(P=0.193)$ in THP-1 cells

Conclusion: Results from our studies provide evidence that ESM hydrolyzates significantly activate NF- $\mathrm{KB}$, and the source of this activity was investigated to confirm that it is inherent to ESM and not derived from bacterial contamination. Based on our findings, we propose a plausible hypothesis as to how increased NF- $\kappa$ B activity might translate into the in vivo efficacy that has been observed with ESM via an "oral tolerance" mechanism.

Keywords: eggshell membrane, NF- $\kappa \mathrm{B}$, lipopolysaccharide, polymyxin B, lipoprotein lipase, hydrolyzate

\section{Introduction}

Eggshell membrane (ESM), found between the calcified shell and the albumin in chicken eggs, is primarily composed of fibrous proteins such as collagen type $\mathrm{I}^{1}$ that form the mesh-like structure of the bilayered material. ESMs have also been shown to contain other bioactive components, namely glycosaminoglycans (ie, dermatan sulfate, ${ }^{2}$ chondroitin sulfate, ${ }^{2}$ and hyaluronic acid ${ }^{3}$ ). ESM is known to reduce the 
expression of various proinflammatory cytokines, including interleukin-1-beta (IL-1 $\beta$ ) and tumor necrosis factor-alpha (TNF- $\alpha$ ) both in vitro ${ }^{4}$ and in vivo. ${ }^{5}$ A proprietary form of ESM, commercially available as the branded product $\mathrm{NEM}^{\circledR}$, has demonstrated safety and efficacy in multiple clinical trials in relieving joint pain and stiffness in humans with osteoarthritis ${ }^{6-8}$ and has been investigated for similar uses in various species of animals. ${ }^{9,10}$ ESM is also reported to have possible beneficial effects in liver fibrosis in rats through regulating gene expression. ${ }^{11}$

Nuclear factor kappa-light-chain-enhancer of activated $\mathrm{B}$-cells (NF- $\mathrm{\kappa B}$ ) is a protein complex found in the cytoplasm of nearly all human and animal cell types; the deoxyribonucleic acid (DNA)-binding activities of this family of transcription factors were first reported in $1986 .{ }^{12}$ Once activated and translocated to the nucleus, NF- $\mathrm{kB}$ regulates the expression of multiple genes involved in the acute response to negative or harmful external cellular stimuli. Active NF- $\kappa B$ is a heterodimeric protein that activates DNA sequences known collectively as $\kappa B$ sites (see ${ }^{13}$ for a detailed overview). There are two well-accepted paths to activation of NF- $\mathrm{kB}$ : the canonical or classical pathway and the noncanonical or alternative pathway. In either pathway (canonical or noncanonical), the inhibitor of $\mathrm{\kappa B}$ kinase complex is activated when signaling molecules bind to cell surface receptors. Bacterial or viral antigens, ${ }^{14,15}$ various cytokines (eg, IL-1 $\beta$, TNF- $\alpha),{ }^{16,17}$ oxidative stress, ${ }^{18,19}$ ultraviolet irradiation, ${ }^{20,21}$ and free radicals ${ }^{22,23}$ are just some of the stimuli known to trigger activation of one or the other of the NF- $\mathrm{KB}$ pathways, either through direct binding to cell surface receptors or by causing other signaling molecules to be formed, which then bind to the receptors.

$\mathrm{NF}-\kappa \mathrm{B}$ was initially investigated for its critical role in regulating the immune response to infection. However, in the decades since its discovery, the dysregulation of NF- $\mathrm{\kappa B}$ has been associated with numerous classical inflammatory diseases such as sepsis, asthma, rheumatoid arthritis, and inflammatory bowel disease (see ${ }^{24-27}$ for a review). Interestingly, a number of diseases that are not obviously inflammatory in nature are also associated with NF- $\mathrm{\kappa B}$ dysregulation, including atherosclerosis, ${ }^{28,29}$ Alzheimer's disease, ${ }^{30,31}$ multiple sclerosis, ${ }^{32,33}$ diabetes, ${ }^{34,35}$ and various cancers. ${ }^{36-38}$

Because of its fundamental importance in immune system function and inflammatory diseases, the studies reported herein were designed to investigate the possible role that $\mathrm{NF}-\kappa \mathrm{B}$ activity might play in the reported biological activities of ESM.

\section{Materials and methods \\ Reagents}

All chemicals and reagents were used as received unless otherwise indicated. High-performance liquid chromatography (HPLC) grade water, sodium bicarbonate, sodium carbonate monohydrate, sodium hydroxide, and filter paper (P4 grade, medium-fine porosity) were obtained from Fisher Scientific (Pittsburgh, PA, USA). Purified alkaline protease from Bacillus licheniformis was obtained from Bio-Cat, Inc. (Troy, VA, USA). ESM (from Gallus gallus) used in the preparation of ESM hydrolyzates was obtained from ESM Technologies, LLC (Carthage, MO, USA). Phosphatebuffered saline (PBS, pH 7.4), Roswell Park Memorial Institute-1640 culture medium, fetal bovine serum (FBS), L-glutamine $200 \mathrm{mM}$, penicillin-streptomycin 100X solution, glacial acetic acid, and methanol were obtained from Sigma-Aldrich Co (St Louis, MO, USA). TransAM ${ }^{\circledR}$ NF- $\mathrm{KB}$ p65 enzyme-linked immunosorbent assay (ELISA) kits were obtained from Active Motif (Carlsbad, CA, USA). Bradford method protein assay kits were obtained from Bio-Rad Laboratories Inc. (Hercules, CA, USA).

\section{Preparation of ESM hydrolyzates}

\section{Fermentation hydrolyzate}

ESM powder $(2.8 \mathrm{~g}$ ) was suspended in $50 \mathrm{~mL}$ of purified water (HPLC grade) in a $100 \mathrm{~mL}$ round-bottomed flask, followed by the addition of $1.4 \mathrm{~g}$ of sucrose and $230 \mu \mathrm{L}$ of a proprietary inoculum of bacteria and yeasts. The slurry was allowed to ferment at room temperature $\left(\sim 25^{\circ} \mathrm{C}\right)$ for 6 hours with moderate stirring $(\sim 500 \mathrm{rpm})$. The slurry was vacuum filtered to remove unreacted solids. The resulting clear, light brown solution contains $5 \%-7 \%$ dissolved solids and was divided into $\sim 1 \mathrm{~mL}$ aliquots, which were stored frozen $\left(-20^{\circ} \mathrm{C}\right)$ until later use in the bioassays. This preparation is referred to as fermentation hydrolyzate of ESM (ESM-FH).

\section{Enzymatic hydrolyzate}

ESM powder (1.0 g) was suspended in a buffer mixture (pH 9.3) comprising $15 \mathrm{~mL}$ of $0.1 \mathrm{M}$ sodium bicarbonate and $5 \mathrm{~mL}$ of $0.1 \mathrm{M}$ sodium carbonate in a $50 \mathrm{~mL}$ round-bottomed flask. Alkaline protease powder $(20 \% \mathrm{w} / \mathrm{w}$ to ESM) was added, and the slurry was allowed to $\operatorname{stir}(\sim 500 \mathrm{rpm})$ at $60^{\circ} \mathrm{C}$ for 5 days. The slurry was vacuum filtered to remove unreacted solids. The resulting clear, light brown solution contains 5\%-7\% dissolved solids and was divided into $\sim 1 \mathrm{~mL}$ aliquots, which were stored frozen $\left(-20^{\circ} \mathrm{C}\right)$ until later use in the bioassays. This preparation is referred to as enzymatic hydrolyzate of ESM (ESM-EH). 


\section{Chemical hydrolyzate}

The hydrolysis was performed according to the method of Strohbehn et al. ${ }^{39}$ Briefly, ESM powder $(1.0 \mathrm{~g})$ was suspended in a $5 \%(\mathrm{w} / \mathrm{v})$ sodium hydroxide solution in a $25 \mathrm{~mL}$ roundbottomed flask. The slurry was allowed to stir ( $\sim 500 \mathrm{rpm})$ at $50^{\circ} \mathrm{C}$ for 4 hours. The mixture was allowed to cool and was vacuum filtered to remove any eggshell. The $\mathrm{pH}$ of the filtrate was adjusted to $\sim 7$ with a $5 \%(\mathrm{w} / \mathrm{v})$ acetic acid solution while keeping the mixture temperature at $\leq 4{ }^{\circ} \mathrm{C}$. The solution was desalted using a dialyzing membrane with two to three equal volumes of water. The resulting clear, pale yellow solution was adjusted to contain 5\%-7\% dissolved solids and was divided into $\sim 1 \mathrm{~mL}$ aliquots, which were stored frozen $\left(-20^{\circ} \mathrm{C}\right)$ until later use in the bioassays. This preparation is referred to as chemical hydrolyzate of ESM (ESM-CH).

\section{Cell source and culture conditions}

Human peripheral blood mononuclear cells (PBMCs) were obtained from Astarte Biologics, LLC (Bothell, WA, USA). PBMCs were cultured at $3.2 \times 10^{6}$ cells/well in culture medium (RPMI-1640 medium supplemented with $10 \%$ FBS, L-glutamine [2 $\mathrm{mM}$ ], penicillin [100 U/mL], and streptomycin $[100 \mathrm{mg} / \mathrm{mL}])$. The human leukemic monocyte cell line THP-1 was obtained from American Type Culture Collection (Manassas, VA, USA) and was cultured at $2.0 \times 10^{5}$ cells/well in culture medium (RPMI-1640 medium supplemented with $10 \%$ FBS, 2-mercaptoethanol [0.05 mM], and $1 \%$ penicillin-streptomycin). Both PBMC and THP-1 cell cultures were utilized for the subsequent determination of $\mathrm{NF}-\kappa \mathrm{B}$ activity.

\section{Evaluation of the in vitro NF- $\kappa B$ activity of ESM hydrolyzates}

The in vitro NF- $\mathrm{KB}$ activity of ESM hydrolyzates was initially evaluated in human PBMCs utilizing the facilities and services of NIS Labs (Klamath Falls, OR, USA). PBMCs were plated at a density of $3.2 \times 10^{6}$ cells/well in culture medium in 12-well culture plates (growth area $3.8 \mathrm{~cm}^{2} /$ well). The primary cells were plated in duplicate in two independent experiments ( $\mathrm{n}=2$ per condition). Aliquots of ESM hydrolyzates (ESM-FH or ESM-EH) were allowed to thaw and were diluted 1:1 with PBS prior to filtering through a 0.22 micron cellulose acetate disc to sterilize them. An additional two tenfold dilutions of the ESM hydrolyzates were prepared with culture medium. Each dilution $(60 \mu \mathrm{L})$ was added to a culture well ( $3 \mathrm{~mL}$ total volume), resulting in final ESM hydrolyzate dilutions of 1:100, $1: 1,000$, and $1: 10,000$, and the cells were incubated at $37^{\circ} \mathrm{C}$, $5 \% \mathrm{CO}_{2}$ for 4 hours. Not knowing whether ESM hydrolyzates would be activating or inhibitory, a known activator of NF-אB, lipopolysaccharide (LPS; $100 \mathrm{ng} / \mathrm{mL}$ ), was used as a positive control, and a known inhibitor of NF- $\mathrm{\kappa B}$, vitamin $\mathrm{C}$ (ascorbic acid; $20 \mathrm{mM}),{ }^{40}$ was used as a comparator of the inhibitory effect on LPS-treated cells. Activity was also compared with untreated cells. Cells were pelleted by centrifuging at $150 \mathrm{xg}$ $(1,200 \mathrm{rpm})$ for 3 minutes and the supernatant was discarded. Cell lysates were prepared from the incubated cultures via bead milling. The whole cell lysates were assayed for NF- $\mathrm{\kappa B}$ activity via a commercially available ELISA kit according to the manufacturer's instructions. Samples were assayed in duplicate and were normalized for total protein content via the Bradford method according to the manufacturer's instructions.

The determination of the in vitro NF- $\mathrm{\kappa B}$ activity of ESM hydrolyzates in THP-1 cells was performed utilizing the facilities and services of the Jordan Valley Innovation Center within the Center for Biomedical and Life Sciences at Missouri State University (JVIC-MSU; Springfield, MO, USA). THP-1 cells were incubated in suspension for 3-5 days and were subsequently plated at a cell density of $2.0 \times 10^{5}$ cells/well in culture medium in 24-well culture plates (growth area $1.9 \mathrm{~cm}^{2} /$ well). The cells were plated using a volume of $350 \mu \mathrm{L}$ per well in duplicate in three independent experiments ( $n=3$ per condition). Aliquots of ESM hydrolyzates (ESM-FH, ESM-EH, or ESM-CH) were allowed to thaw prior to filtering through a 0.2 micron polyethersulfone disc to sterilize them. The ESM hydrolyzates were then diluted $(1: 1,000 ; 1: 10,000)$ with culture medium. Each dilution was added to a culture well ( $3 \mathrm{~mL}$ total volume), and the cells were incubated at $37^{\circ} \mathrm{C}, 5 \% \mathrm{CO}_{2}$ for 4 hours. Because ESM hydrolyzates were found to be activating in PBMCs, only LPS $(10 \mathrm{ng} / \mathrm{mL})$ was used as a positive control. Activity was again compared with untreated cells. Cells were pelleted by centrifuging at $150 \mathrm{xg}(1,200 \mathrm{rpm})$ for 3 minutes and the supernatant was discarded. Cell lysates were prepared from the incubated cultures by adding $45 \mu \mathrm{L}$ of complete lysis buffer (containing dithiothreitol and protease inhibitor). The whole cell lysates were assayed for NF- $\mathrm{KB}$ activity via a commercially available ELISA kit according to the manufacturer's instructions. Samples were assayed in duplicate and were normalized for total protein content via the Bradford method according to the manufacturer's instructions.

\section{Evaluation of the ESM source of NF- $\kappa B$ activation}

An initial evaluation of the source of NF-אB activity was performed utilizing the facilities of NIS Labs using respective appropriate controls. PBMCs (prepared as described 
previously) were exposed to aliquots of ESM hydrolyzate or control solutions for 4 hours prior to NF- $\kappa B$ activity determination. ESM-FH NF- $\kappa \mathrm{B}$ activity was compared with untreated cells and cells treated with the fermentation broth (minus ESM). Similarly, the ESM-EH was compared with untreated cells and cells treated with the enzyme digest solution alone. A further, more discerning, evaluation of the source of in vitro NF- $\kappa$ B activity of ESM hydrolyzates in THP-1 cells was performed utilizing the facilities and services of JVIC-MSU. THP-1 cells were prepared as described previously. Aliquots of ESM hydrolyzates (ESM-FH, ESM-EH, or ESM-CH) were allowed to thaw prior to filtering through a 0.2 micron polyethersulfone disc to sterilize them. The ESM hydrolyzates were then diluted $(1: 1,000 ; 1: 10,000)$ with culture medium. Each dilution was added to a culture well as well as separate wells for hydrolyzate + polymyxin B $(10 \mathrm{mg} / \mathrm{mL})$ and hydrolyzate + lipoprotein lipase $(10 \mathrm{mg} / \mathrm{mL})$. The cells were incubated at $37^{\circ} \mathrm{C}, 5 \% \mathrm{CO}_{2}$ for 4 hours. LPS $(10 \mathrm{ng} / \mathrm{mL})$ was again used as a positive control. Activity was compared with untreated cells, cells treated with polymyxin B only, cells treated with LPS + polymyxin B, and cells treated with lipoprotein lipase only. Cell cultures were processed and whole cell lysates were analyzed as described previously.

\section{Statistical analysis}

Statistical analyses were done either as a two-tailed, independent group Student's $t$-test or a Kruskal-Wallis test for multiple comparisons. Statistical significance was accepted at a $P$-value of $P<0.05$. SYSTAT software (version 13 ) was used for all statistical analyses. ${ }^{41}$

\section{Results}

\section{Evaluation of the in vitro NF- $\kappa B$ activity of ESM hydrolyzates}

There were statistically significant levels of NF- $\mathrm{KB}$ activation versus untreated cells at all three dilutions $(1: 100$, $1: 1,000$, and $1: 10,000)$ for the ESM-FH $(P=0.021, P=0.020$, $P=0.009$, respectively) in PBMCs. The ESM-EH also showed statistically significant levels of activation at the $1: 100$ and $1: 1,000$ dilutions $(P=0.004, P=0.006$, respectively) but fell just shy of significance at the 1:10,000 dilution $(P=0.073)$. Both the fermentation and enzymatic hydrolyzates of ESM at the 1:100 and 1:1,000 dilutions activated NF- $\kappa$ B in human PBMCs comparably with LPS at $100 \mathrm{ng} / \mathrm{mL}$ (Figure 1).

Similarly, there were statistically significant levels of $\mathrm{NF}-\kappa \mathrm{B}$ activation versus untreated cells at both dilutions $(1: 1,000$ and $1: 10,000)$ for the fermentation and enzymatic hydrolyzates of ESM (ESM-FH: $P=0.021, P=0.002$; ESMEH: $P=0.007, P=0.007$, respectively) in THP-1 cells. The ESM-CH also caused statistically significant levels of activation at the $1: 1,000$ dilution $(P=0.005)$ but failed to differ from untreated cells at the $1: 10,000$ dilution $(P=0.193)$. Both the fermentation and enzymatic hydrolyzates of ESM at the

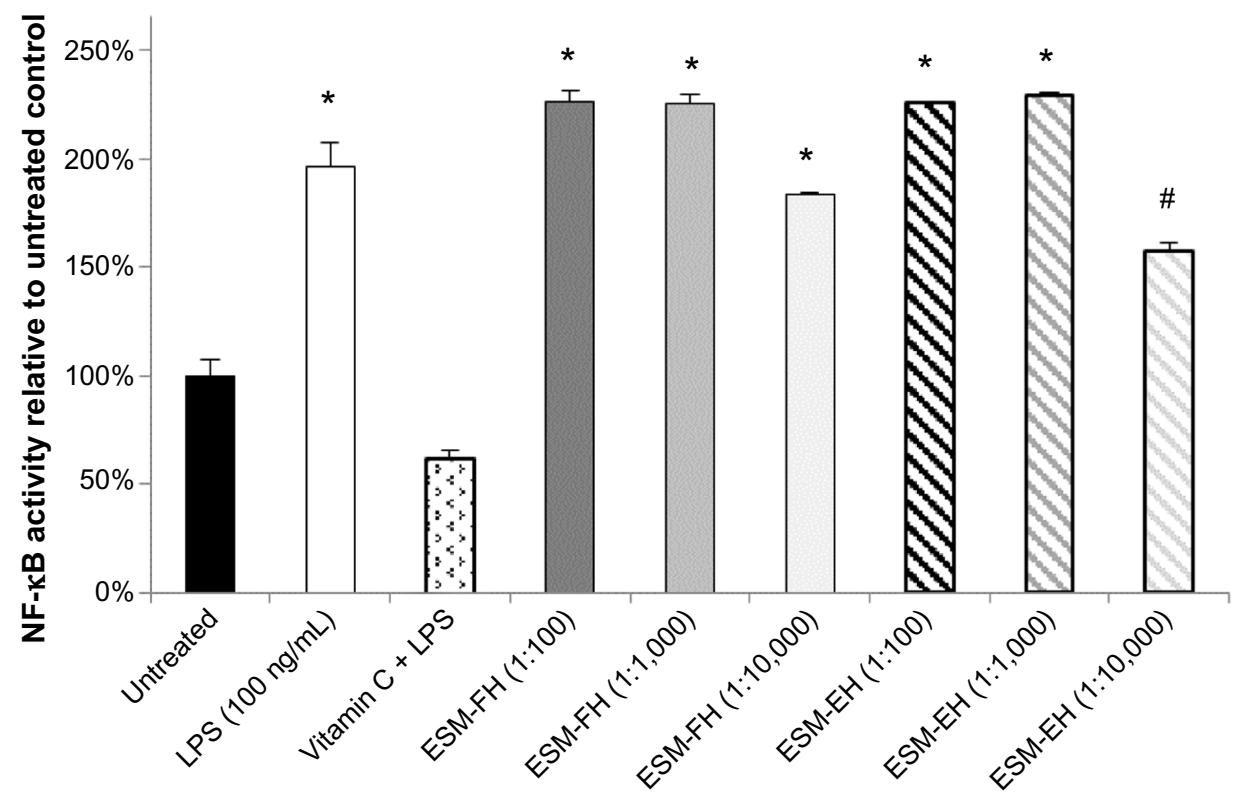

Figure I NF-KB activity of fermentation and enzymatic hydrolyzates of ESM in human PBMCs. Human PBMCs were incubated for 4 hours with either medium (untreated control), LPS, vitamin C + LPS, or each dilution of ESM hydrolyzate. Whole cell lysates were then analyzed for NF- $\kappa B$ activity after normalizing for protein content. Bars represent mean \pm standard error of the mean; values are presented relative to untreated control.

Notes: $* P<0.05$ versus untreated control; ${ }^{*} P<0.10$ versus untreated control.

Abbreviations: NF- $\mathrm{KB}$, nuclear factor kappa-light-chain-enhancer of activated B-cells; ESM, egg shell membrane; PBMCs, peripheral blood mononuclear cells; LPS, lipopolysaccharide; ESM-FH, ESM fermentation hydrolyzate; ESM-EH, ESM enzymatic hydrolyzate. 
1:1,000 dilution activated NF- $\mathrm{\kappa B}$ in human THP-1 cells comparably with LPS at $10 \mathrm{ng} / \mathrm{mL}$ (Figure 2).

\section{Evaluation of the ESM source of NF- $\mathrm{KB}$ activation}

No increased NF- $\kappa B$ activity was observed in the cells treated with fermentation broth alone; however, ESM-FH activity was similar to what was observed previously (data not shown). Similarly, no increased NF- $\mathrm{\kappa B}$ activity was observed with enzyme digest alone; however, ESMEH activity was similar to what was observed previously (data not shown). Polymyxin B $(10 \mathrm{mg} / \mathrm{mL})$ adequately inhibited activation by LPS at $10 \mathrm{ng} / \mathrm{mL}$ (Figure 3) but showed a small degree of NF- $\kappa$ B activation itself (although not statistically significant). Lipoprotein lipase had no significant impact on NF- $\mathrm{KB}$ activity when used alone. These effects were confirmed in the separate bioassays of all three hydrolyzates (data not shown). There was no statistically significant difference between the ESM hydrolyzate alone samples and the ESM hydrolyzate + polymyxin B samples for any of the hydrolyzates tested $(1: 10,000$ dilution) (ESM-FH, $P=0.262$; ESM-EH, $P=0.727$; ESM-CH, $P=0.240$ ). Similarly, there was no statistically significant difference between the ESM hydrolyzate alone samples and the ESM hydrolyzate + lipoprotein lipase samples for any of the hydrolyzates tested (1:10,000 dilution) (ESM-FH, $P=0.539$; ESM-EH, $P=0.855$; ESM-CH, $P=0.281)$. Data for ESM-FH are presented in Figure 4 .

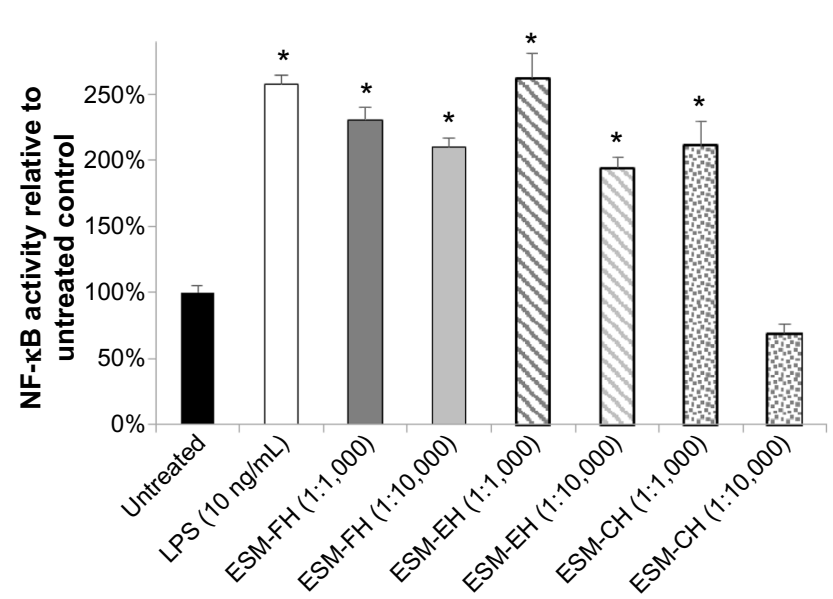

Figure 2 NF- $\mathrm{KB}$ activity of fermentation, enzymatic, and chemical hydrolyzates of ESM in the human THP-I monocyte cell line. Human THP-I monocytes were incubated for 4 hours with either medium (untreated control), LPS, or each dilution of ESM hydrolyzate. Whole cell lysates were then analyzed for NF- $\kappa B$ activity after normalizing for protein content. Bars represent mean \pm standard error of the mean; values are presented relative to untreated control.

Note: $* P<0.05$ versus untreated control.

Abbreviations: NF- $\kappa B$, nuclear factor kappa-light-chain-enhancer of activated B-cells; ESM, egg shell membrane; LPS, lipopolysaccharide; ESM-FH, ESM fermentation hydrolyzate; ESM-EH, ESM enzymatic hydrolyzate; ESM-CH, ESM chemical hydrolyzate.

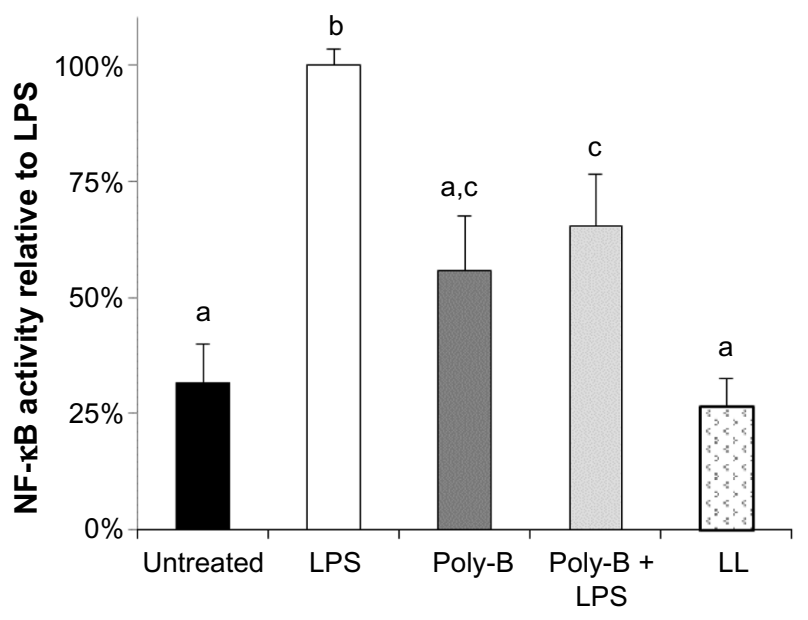

Figure 3 Effects of poly-B and LL on in vitro NF-KB activity in untreated and LPStreated THP-I monocytes. Human THP-I monocytes were incubated for 4 hours with either medium (untreated control), LPS, poly-B, poly-B + LPS, or LL. Whole cell lysates were then analyzed for NF-KB activity after normalizing for protein content. Bars represent mean \pm standard error of the mean; values are presented relative to LPS. Note: Columns with differing letters are statistically $(P<0.05)$ different.

Abbreviations: poly-B, polymyxin $B$; LL, lipoprotein lipase; NF- $\kappa B$, nuclear factor kappa-light-chain-enhancer of activated B-cells; LPS, lipopolysaccharide.

Similar results were observed for ESM-EH and ESM-CH (data not shown).

\section{Discussion}

$\mathrm{NF}-\mathrm{KB}$ is of fundamental importance to the functioning of innate immunity. Its dysregulation is implicated in the pathology of a considerable variety of human diseases. The

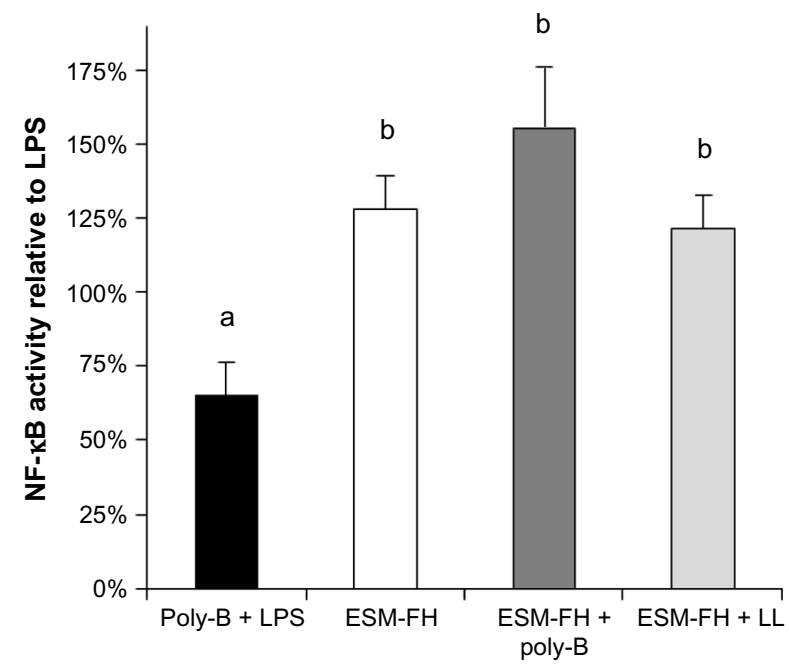

Figure 4 NF- $\mathrm{KB}$ activity of a fermentation hydrolyzate of ESM in THP-I monocytes with and without poly-B or LL. Human THP-I monocytes were incubated for 4 hours with either poly-B + LPS, ESM-FH alone (I:10,000 dilution), ESM-FH + poly-B, or ESM-FH + LL. Whole cell lysates were then analyzed for NF- $\kappa B$ activity after normalizing for protein content. Bars represent mean \pm standard error of the mean; values are presented relative to LPS.

Note: Columns with differing letters are statistically $(P<0.05)$ different.

Abbreviations: NF- $\mathrm{KB}$, nuclear factor kappa-light-chain-enhancer of activated B-cells; ESM, egg shell membrane; poly-B, polymyxin B; LL, lipoprotein lipase; LPS, lipopolysaccharide; ESM-FH, ESM fermentation hydrolyzate. 
goal of our studies was to investigate the potential role NF- $\kappa B$ might play in the beneficial biological activities reported previously for ESM. ESM hydrolyzates were chosen for our studies because of 1 ) the simplicity of their addition to cell cultures, 2) the variety of preparation methods available (eg, fermentation, enzymatic, or chemical), and 3) the potential to generate bioactive substances possessing differing activity profiles. Human PBMCs obtained from healthy volunteers were initially chosen for these studies owing to the wide variety of mononuclear cells present in this source (eg, T-lymphocytes, B-lymphocytes, natural killer cells, monocytes, and dendritic cells). ${ }^{42,43}$ Readily available THP-1 monocytes were subsequently used because of their antigen presenting characteristics that are similar to those of dendritic cells found in the gut, which are not readily available.

At the outset, it was unknown whether ESM hydrolyzates would stimulate or inhibit active levels of NF- $\kappa$ B. Previous work $^{4}$ in which an extract of ESM was shown to reduce the expression of proinflammatory cytokines in mitogenchallenged human PBMCs provided preliminary data that the hydrolyzates' effect on NF- $\kappa$ B would be inhibitory. The data reported here show that ESM hydrolyzates significantly activate NF- $\kappa \mathrm{B}$ in unstimulated cells. The ESM-FH and the ESM-EH showed quite similar activities in both PBMCs and THP-1 cell cultures. The ESM-CH, however, was about tenfold less active than the other hydrolyzates in THP-1 monocytes. As seen in Figure 2, the 1:1,000 dilution of ESM-CH had approximately the same activity as the 1:10,000 dilutions of ESM-FH and ESM-EH. This result is logically consistent with the differing specificities of the hydrolysis conditions. That is, both microorganisms and purified enzymes will be fairly specific in their sites of hydrolysis within the ESM protein structure, whereas chemical hydrolysis is quite indiscriminate. It is likely that the NF- $\mathrm{BB}$-activating soluble peptides that are formed initially during hydrolysis are being further degraded by the harsh chemical conditions, resulting in lower activity in cell culture.

Because ESM hydrolyzates induced increased levels of $\mathrm{NF}-\kappa \mathrm{B}$, we felt it necessary to broadly explore the possible sources of this activity. Our immediate concern was to determine whether the activity was inherent in ESM or if it was due to materials used to produce the hydrolyzates (ie, fermentation inoculum or enzyme) or to some other type of contaminant. As neither the fermentation inoculum nor the enzyme produced elevated NF- $\mathrm{KB}$ activity, it was necessary to consider alternative sources for the observed activity. Degradation products of extracellular matrix components, such as fibronectin, collagen, proteoglycans, and hyaluronan, are believed to play a significant role in the pathogenesis of both osteo- and rheumatoid arthritis, likely through autoimmune mechanisms, ${ }^{44-46}$ and at least some of these components do so via activation of NF- $\kappa \mathrm{B} .{ }^{47,48}$ Hyaluronan, ${ }^{3}$ proteoglycans, ${ }^{2}$ and collagens ${ }^{1}$ all naturally occur in ESM and may be responsible for at least part of the activity reported here. However, they occur at relatively low levels, up to $2 \%$ each hyaluronan and proteoglycans and up to $5 \%$ collagen. Therefore, we speculate that other sources may provide a more likely explanation for the observed stimulatory activity.

Bacterial cellular components and DNA have been found in the joints of patients suffering from a variety of arthritides, ${ }^{49}$ and the innate immune response to these contaminants is believed to play a possible role in the pathogenesis of these diseases. ${ }^{50,51}$ Additionally, Pugh et $\mathrm{l}^{52}$ found that the majority of in vitro macrophage activation exhibited by extracts of a number of common "immune enhancing" botanicals (Echinacea, ginseng, and alfalfa) was not inherent in the botanical compounds themselves but was due to contamination with bacterial cellular components such as bacterial lipoproteins and LPS. Being a natural product, it was logical that ESM would be contaminated with various microbial species. Although the ESM was heat treated to substantially reduce the living bioburden prior to hydrolysis, the cellular components from the formerly living microorganisms would remain.

Intact microorganisms should have been removed during filtration of the hydrolyzates through 0.2 micron filter membranes prior to the initial assays; however, cellular fragments from these microorganisms could not be ruled out as the source of activation. Therefore, we investigated the possible contribution of LPS and/or bacterial lipoprotein to the observed activation of NF- $\kappa$ B by ESM hydrolyzates. LPS activity is abrogated by the long-known antibiotic polymyxin $\mathrm{B},{ }^{53}$ and the enzyme lipoprotein lipase deactivates bacterial lipoprotein through cleavage of the lipid-protein bond. ${ }^{52}$ All three hydrolyzates (ESM-FH, ESM-EH, and ESM-CH) were evaluated alone and in combination with either polymyxin $\mathrm{B}$ or lipoprotein lipase. If a significant proportion of the NF- $\kappa B$ activity of the hydrolyzates was derived from either of these bacterial cellular components, the polymyxin B-treated and lipoprotein lipasetreated cells would have exhibited substantially decreased activity compared with the hydrolyzates alone. However, no differences were observed between the ESM hydrolyzates alone and either the ESM hydrolyzates + polymyxin B or ESM hydrolyzates + lipoprotein lipase. With no evidence that the NF- $\kappa \mathrm{B}$ activation by ESM hydrolyzates is derived from bacterial cellular components, it would seem that this activity is attributable to the inherent bioactive components present 
in ESM. Further work will be needed to elucidate whether this activity draws from known stimulatory components of ESM (hyaluronan, proteoglycans, collagens) or from an as yet unidentified peptide or peptides produced from the various hydrolysis conditions.

Since the vast majority of NF- $\kappa \mathrm{B}$ dysregulation encountered in disease pathology is that of elevated or inappropriately activated NF- $\mathrm{KB},{ }^{24-27}$ it would seem counterintuitive that ESM hydrolyzates activating NF- $\kappa B$ would contribute to ESM's observed in vivo efficacy. Here we raise the possibility that this efficacy is achieved through an "oral tolerance" mechanism. Oral tolerance refers to the phenomenon of a reduced peripheral immune response (tolerance) that results from the repeated exposure of the mucosal immune system in the gut to ingested protein antigens. Oral tolerance to immunogenic peptides that are repeatedly ingested is believed to result from immune surveillance within the gut-associated lymphoid tissue as a way for the body to prevent an inappropriate or unnecessary immune response to proteins normally consumed in the diet. This tolerogenic behavior is thought to occur through the presentation of these peptides by antigen-presenting cells in the gut-associated lymphoid tissue to circulating T-cells, causing them to transform into regulatory $\mathrm{T}$-cells $\left(\mathrm{T}_{\text {reg }}\right.$ cells), which results in anergy and even active suppression by these cells when they return to circulation. ${ }^{54,55}$ Oral tolerance has been shown to be effective in a variety of autoimmune diseases, including arthritis, diabetes, colitis, and multiple sclerosis (see ${ }^{56}$ and ${ }^{57}$ for a review). There has been particular attention paid to autoimmune arthritides in this area of research in which cartilage autoantigens (particularly type II collagen) produce antigen-specific suppression of the immune response. In addition, "bystander suppression", wherein $\mathrm{T}_{\text {reg }}$ cells produce a higher proportion of general anti-inflammatory cytokines (eg, IL-4, IL-10, and transforming growth factor-beta) suppressing the local autoimmune reaction independently of the antigen type, is also an active area of arthritis research. ${ }^{58,59}$ Further work will be needed to investigate whether ESM might function via 1) antigen-specific immune suppression from its extracellular matrix content (ie, collagen, proteoglycans, and hyaluronan), 2) bystander suppression, 3) some unrelated mechanism, or 4) some combination of these.

\section{Conclusion}

A great deal of research has been conducted relating to $\mathrm{NF}-\kappa \mathrm{B}$ since its discovery, particularly in the last couple of decades, and with so many people suffering from diseases involving its dysregulation, this trend is sure to increase. We presented here results that ESM hydrolyzates produced via three different hydrolysis conditions (ie, fermentation, enzymatic, and chemical) activate NF- $\mathrm{KB}$ in both human primary cells and a human leukemic cell line. The source of this activity was also investigated to confirm that it is inherent to ESM and not derived from hydrolysis conditions or from bacterial contamination. We also proposed a plausible hypothesis, via an oral tolerance mechanism, as to how this $\mathrm{NF}-\kappa \mathrm{B}$ activity might translate into the in vivo efficacy that has been previously observed with ESM. Further work is needed to confirm this proposed mechanism of action and to possibly identify the component(s) of ESM that is/are the source of the reported activity.

\section{Acknowledgment}

The sponsor of the studies was ESM Technologies, LLC.

\section{Author contributions}

KJR conceived of the study and participated in its design and coordination, conducted the statistical analyses, and drafted the manuscript. PLD participated in the design of the study and helped to draft the manuscript. AO participated in the design of the study, carried out the cell culture work and immunoassays, and reviewed the manuscript. FDL participated in the design of the study, prepared all of the hydrolyzates for use in the study, and reviewed the manuscript. All authors read and approved the final manuscript.

\section{Disclosure}

KJR and FDL are employed by the sponsor of the studies. $\mathrm{PLD}$ and $\mathrm{AO}$ have no competing interests.

\section{References}

1. Wong M, Hendrix MJC, von der Mark K, Little C, Stern R. Collagen in the egg shell membranes of the hen. Dev Biol. 1984;104(1):28-36.

2. Baker JR, Balch DA. A study of the organic material of hen's-egg shell. Biochem J. 1962;82:352-361.

3. Long FD, Adams RG, DeVore DP, inventors. Preparation of hyaluronic acid from eggshell membrane. United States patent US 6946551. September 20, 2005.

4. Benson KF, Ruff KJ, Jensen GS. Effects of natural eggshell membrane (NEM) on cytokine production in cultures of peripheral blood mononuclear cells: increased suppression of tumor necrosis factor- $\alpha$ levels after in vitro digestion. J Med Food. 2012;15(4):360-368.

5. Ruff KJ, DeVore DP. Reduction of pro-inflammatory cytokines in rats following 7-day oral supplementation with a proprietary eggshell membrane-derived product. Mod Res Inflamm. 2014;3(1):19-25.

6. Ruff KJ, DeVore DP, Leu MD, Robinson MA. Eggshell membrane: a possible new natural therapeutic for joint and connective tissue disorders. Results from two open-label human clinical studies. Clin Interv Aging. 2009;4:235-240.

7. Ruff KJ, Winkler A, Jackson RW, DeVore DP, Ritz BW. Eggshell membrane in the treatment of pain and stiffness from osteoarthritis of the knee: a randomized, multicenter, double-blind, placebo-controlled clinical study. Clin Rheumatol. 2009;28:907-914. 
8. Danesch U, Seybold M, Rittinghausen R, Treibel W, Bitterlich N. NEM ${ }^{\circledR}$ brand eggshell membrane effective in the treatment of pain associated with knee and hip osteoarthritis: results from a six-center, open-label German clinical study. J Arthritis. 2014;3(3):136.

9. Bauer KL, Dierenfeld ES, Hartup BK. Evaluation of a nutraceutical joint supplement in cranes. Proc North Am Crane Workshop. 2014;12: 27-32.

10. Dierenfeld ES, Baum D, Hampe L, Jensen J, Atwell C, Wedekind K. Evaluation of a nutraceutical joint supplement in camels. Amer Hol Vet Med Assoc J. 2014;39:59-66.

11. Jia H, Saito K, Aw W, et al. Transcriptional profiling in rats and an ex vivo analysis implicate novel beneficial function of egg shell membrane in liver fibrosis. J Funct Foods. 2013;5:1611-1619.

12. Sen R, Baltimore D. Multiple nuclear factors interact with the immunoglobulin enhancer sequences. Cell. 1986;46:705-716.

13. Gilmore TD. Introduction to NF- $\mathrm{KB}$ : players, pathways, perspectives. Oncogene. 2006;25:6680-6684.

14. Akira S, Uematsu S, Takeuchi O. Pathogen recognition and innate immunity. Cell. 2006;124:783-801.

15. Hayden M, West A, Ghosh S. NF-kB and the immune response. Oncogene. 2006;25:6758-6780.

16. Beg A, Finco T, Nantermet P, Baldwin A. Tumor necrosis factor and interleukin-1 lead to phosphorylation and loss of IKBa: a mechanism for NF-אB activation. Mol Cell Biol. 1993;13(6):3301-3310.

17. Flodstriim M, Welsh N, Eizirik D. Cytokines activate the nuclear factor $\mathrm{kB}(\mathrm{NF}-\mathrm{\kappa B})$ and induce nitric oxide production in human pancreatic islets. FEBS Letters. 1996;385:4-6.

18. Schreck R, Albermann K, Baeuerle P. Nuclear factor kB: an oxidative stress-responsive transcription factor of eukaryotic cells (a review). Free Rad Res Comms. 1992;17(4):221-237.

19. Scandalios J. Oxidative stress: molecular perception and transduction of signals triggering antioxidant gene defenses. Braz J Med Biol Res. 2005;38:995-1014.

20. Cooper S, Bowden G. Ultraviolet B regulation of transcription factor families: roles of nuclear factor-kappa $\mathrm{B}(\mathrm{NF}-\mathrm{\kappa B})$ and activator protein-1 (AP-1) in UVB-induced skin carcinogenesis. Curr Cancer Drug Targets. 2007;7:325-334.

21. Reelfs O, Tyrrell R, Pourzand C. Ultraviolet A radiation-induced immediate iron release is a key modulator of the activation of NF- $\mathrm{KB}$ in human skin fibroblasts. J Invest Dermatol. 2004;122:1440-1447.

22. Kono H, Rusyn I, Yin M, et al. NADPH oxidase-derived free radicals are key oxidants in alcohol-induced liver disease. J Clin Invest. 2000; $106: 867-872$.

23. She H, Xiong S, Lin M, Zandi E, Giulivi C, Tsukamoto H. Iron activates NF- $\kappa$ B in Kupffer cells. Am J Physiol Gastrointest Liver Physiol. 2002;283:G719-G726.

24. Yamamoto Y, Gaynor R. Role of the NF- $\kappa B$ pathway in the pathogenesis of human disease states. Curr Mol Med. 2001;1:287-296.

25. Prajapati B, Singhal M, Yashwant, Sharma G, Gupta V. Role of NFkB in various immunological and inflammatory disorders. Int $J$ Toxicol Pharmacol Res. 2010;2(1):35-39.

26. Courtois G, Gilmore T. Mutations in the NF- $\kappa B$ signaling pathway: implications for human disease. Oncogene. 2006;25:6831-6843.

27. Tak P, Firestein G. NF-кB: a key role in inflammatory diseases. J Clin Invest. 2001;107(1):7-11.

28. Brand K, Page S, Rogler G, et al. activated transcription factor nuclear factor-kappa B is present in the atherosclerotic lesion. J Clin Invest. 1996;97(7):1715-1722.

29. Hajra L, Evans A, Chen M, Hyduk S, Collins T, Cybulsky M. The NF-kappa B signal transduction pathway in aortic endothelial cells is primed for activation in regions predisposed to atherosclerotic lesion formation. Proc Natl Acad Sci U S A. 2000;97(16):9052-9057.

30. Akama K, Albanese C, Pestell R, Van Eldik L. Amyloid $\beta$-peptide stimulates nitric oxide production in astrocytes through an NFKB-dependent mechanism. Proc Natl Acad Sci U SA. 1998;95(10): $5795-5800$
31. Akama K, Van Eldik L. $\beta$-amyloid stimulation of inducible nitric-oxide synthase in astrocytes is interleukin-1 $1 \beta$ - and tumor necrosis factor- $\alpha$ (TNF $\alpha$ )-dependent, and involves a TNF $\alpha$ receptor-associated factor- and NFKB-inducing kinase-dependent signaling mechanism. $J$ Biol Chem. 2000;275(11):7918-7924.

32. Miterski B, Bohringer S, Klein W, et al. Inhibitors in the NFkappaB cascade comprise prime candidate genes predisposing to multiple sclerosis, especially in selected combinations. Genes Immun. 2002;3: 211-219.

33. Yan J, Greer J. NF-kappa B, a potential therapeutic target for the treatment of multiple sclerosis. CNS Neurolog Disord Drug Targets. 2008;7(6):536-557.

34. Patel S, Santani D. Role of NF- $\mathrm{KB}$ in the pathogenesis of diabetes and its associated complications. Pharmacol Rep. 2009;61:595-603.

35. Andreasen A, Kelly M, Berg R, Møller K, Pedersen B. Type 2 diabetes is associated with altered NF- $\mathrm{KB}$ DNA binding activity, JNK phosphorylation, and AMPK phosphorylation in skeletal muscle after LPS. PLoS One. 2011;6(9):e23999.

36. Basseres $\mathrm{D}$, Baldwin $\mathrm{A}$. Nuclear factor- $\mathrm{\kappa B}$ and inhibitor of $\kappa \mathrm{B}$ kinase pathways in oncogenic initiation and progression. Oncogene. 2006;25: 6817-3830.

37. Kordes U, Krappmann D, Heissmeyer V, Ludwig W, Scheidereit C. Transcription factor NF-kappaB is constitutively activated in acute lymphoblastic leukemia cells. Leukemia. 2000;14:399-402.

38. Bauerle KT, Schweppe RE, Haugen BR. Inhibition of nuclear factorkappa B differentially affects thyroid cancer cell growth, apoptosis, and invasion. Mol Cancer. 2010;9:117.

39. Strohbehn RE, Etzel LR, Figgins J, inventors. Solubilized protein composition obtained from avian eggshell membrane. United States patent US 8173174. May 8, 2012.

40. Bowie AG, O'Neill LAJ. Vitamin C inhibits NF- $\kappa$ B activation by TNF via the activation of $\mathrm{p} 38$ mitogen-activated protein kinase. J Immunol. 2000;165(12):7180-7188.

41. Systat Software, Inc. Available at: http://www.systat.com. Accessed January 6, 2015.

42. Reichert T, DeBruyere M, Deneys V, et al. Lymphocyte subset reference ranges in adult caucasians. Clin Immunol Immunopathol. 1991;60: 190-208.

43. Jentsch-Ullrich K, Koenigsmann M, Mohren M, Franke A. Lymphocyte subsets' reference ranges in an age- and gender-balanced population of 100 healthy adults: a monocentric German study. Clin Immunol. 2005;116(2):192-197.

44. Homandberg GA, Davis G, Maniglia C, Shrikhande A. Cartilage chondrolysis by fibronectin fragments causes cleavage of aggrecan at the same site as found in osteoarthritic cartilage. Osteoarthritis Cartilage. 1997;5(6):450-453.

45. Yoshida M, Tsuji M, Kurosaka D, et al. Autoimmunity to citrullinated type II collagen in rheumatoid arthritis. Mod Rheumatol. 2006;16(5): 276-281.

46. György B, Tóthfalusi L, Nagy G, et al. Natural autoantibodies reactive with glycosaminoglycans in rheumatoid arthritis. Arthritis Res Ther. 2008;10:R110.

47. Noble PW, McKee CM, Cowman M, Shin HS. Hyaluronan fragments activate an NF-kappa B/I-kappa B alpha autoregulatory loop in murine macrophages. J Exp Med. 1996;183(5):2373-2378.

48. Saklatvala J. Inflammatory signaling in cartilage: MAPK and NF- $\mathrm{KB}$ pathways in chondrocytes and the use of inhibitors for research into pathogenesis and therapy of osteoarthritis. Curr Drug Targets. 2007;8: 305-313.

49. Van Der Heijden IM, Wilbrink B, Tchetverikov I, et al. Presence of bacterial DNA and bacterial peptidoglycans in joints of patients with rheumatoid arthritis and other arthritides. Arthritis Rheum. 2000;43(3): 593-598.

50. Scanzello CR, Plaas A, Crow MK. Innate immune system activation in osteoarthritis: is osteoarthritis a chronic wound? Curr Opin Rheumatol. 2008;20(5):565-572. 
51. Klinman D. Does activation of the innate immune system contribute to the development of rheumatoid arthritis? Arthritis Rheum. 2003;48(3): 590-593.

52. Pugh ND, Tamta H, Balachandran P, et al. The majority of in vitro macrophage activation exhibited by extracts of some immune enhancing botanicals is due to bacterial lipoproteins and lipopolysaccharides. Int Immunopharmacol. 2008;8(7):1023-1032.

53. Morrison DC, Jacobs DM. Inhibition of lipopolysaccharide-initiated activation of serum complement by polymyxin B. Infect Immun. 1976;13(1):298-301.

54. Friedman A, Weiner HL. Induction of anergy or active suppression following oral tolerance is determined by antigen dosage. Proc Natl Acad Sci U S A. 1994;91(14):6688-6692.
55. Faria AMC, Weiner HL. Oral tolerance. Immunol Rev. 2005;206(1): 232-259.

56. Garside P, Mowat AM, Khoruts A. Oral tolerance in disease. Gut. 1999;44(1):137-142.

57. Faria AMC, Weiner HL. Oral tolerance: therapeutic implications for autoimmune diseases. Clin Dev Immunol. 2006;13(2-4):143-157.

58. Stancikova M, Stancik R, Gubzova Z, Rovensky J. Collagen in the treatment of rheumatic diseases: oral tolerance. Bratisl Med J. 1999;100(10):567-571.

59. Broere F, Wieten L, Koerkamp EIK, et al. Oral or nasal antigen induces regulatory $\mathrm{T}$ cells that suppress arthritis and proliferation of arthritogenic T cells in joint draining lymph nodes. J Immunol. 2008;181(2): 899-906.

\section{Publish your work in this journal}

The Journal of Inflammation Research is an international, peer-reviewed open-access journal that welcomes laboratory and clinical findings on the molecular basis, cell biology and pharmacology of inflammation including original research, reviews, symposium reports, hypothesis formation and commentaries on: acute/chronic inflammation; mediators of inflamma-

\section{Dovepress}

tion; cellular processes; molecular mechanisms; pharmacology and novel anti-inflammatory drugs; clinical conditions involving inflammation. The manuscript management system is completely online and includes a very quick and fair peer-review system. Visit http://www.dovepress.com/ testimonials.php to read real quotes from published authors.

Submit your manuscript here: http://www.dovepress.com/journal-of-inflammation-research-journal 